\title{
DNA Methylation is a Determinative Element of Photosynthesis Gene Expression in Amyloplasts from Liquid-Cultured Cells of Sycamore (Acer pseudoplatanus L.)
}

\author{
Jarunya Ngernprasirtsiri' ${ }^{11}$, Hirokazu Kobayashi²), and Takashi Akazawa ${ }^{\text {* }}$ * \\ ${ }^{1}$ Research Institute for Biochemical Regulation, School of Agriculture, and ${ }^{2}$ Radioisotope Research Center, \\ Nagoya University, Chikusa, Nagoya 464-01, Japan
}

Key words: Acer pseudoplatanus/amyloplast/DNA methylation/gene suppression/in vitro transcription/plastid RNA polymerase

\begin{abstract}
$A B S T R A C T$. Transcriptional regulation has been shown to operate as a selective control mechanism of expression of photosynthetic genes in the nonphotosynthetic plastids, amyloplasts, of a white-wild cell line of sycamore (Acer pseudoplatanus L.). To elaborate the mechanisms governing the transcriptional regulation at the molecular level, we have examined the template activity of the amyloplast DNA compared to the chloroplast DNA by using the in vitro run-off transcription assay system with extracts of the two plastid types. The results of these assays clearly indicate that most of the amyloplast DNA regions do not serve as a template for the in vitro transcription regardless of the plastid extracts; this is in contrast to the chloroplast DNA which serves as an active template. It is highly likely that the template activity of amyloplast DNA per se is the modulating element of transcriptional regulation. Parallel experiments determining the DNA base content by HPLC analysis have shown that a variety of methylated bases, especially 5-methylcytosine, are localized in the DNA regions containing suppressed genes of the amyloplast genome. In sharp contrast, methylated bases were undetectable in the expressed gene regions of amyloplast and whole chloroplast genomes. The overall findings strongly support the notion that DNA methylation is involved in the selective suppression of photosynthetic genes in the nonphotosynthetic plastids of cultured sycamore cells.
\end{abstract}

Differentiated plastids in higher plants such as developed chloroplasts in greening seedlings have been known to exhibit significant changes in transcript levels. The possibility that transcriptional regulation may play a key role in regulating the gene expression during plastid development has spurred early investigations into this organelle (for recent reviews, see 17, 18, 28). However, it is as yet unclear whether these changes in the transcript levels are the results of (a) adjustments in the level of trans-acting factor(s) involved in transcription, (b) the level and specificity of plastid RNA polymerase, (c) modulation of template availability, (d)

\footnotetext{
* To whom Correspondence should be addressed.

Abbreviations: $\mathrm{CF}_{1}$, chloroplast coupling factor one; 2,4-D, 2,4dichlorophenoxyacetic acid; HPLC, high-performance liquid chromatography; RuBisCO, ribulose-1, 5-bisphosphate carboxylase/oxymonogenase; TCA, trichloroacetic acid.

Gene designations: act, actin; atp $\mathrm{A}, \alpha$-subunit of $\mathrm{CF}_{1} ;$ atp $\mathrm{B}, \mathrm{E}, \beta$, $\varepsilon$-subunits of $\mathrm{CF}_{1} ; p s a \mathrm{~A}$, apoprotein of $\mathrm{P} 700 ; p s b \mathrm{~A}, 32-\mathrm{kDa} \mathrm{D}_{1}$ protein; $r b c \mathrm{~L}$, large subunit of RuBisCO; $r b c \mathrm{~S}$, small subunit of RuBisCO; rpoA, $\alpha$-subunit of RNA polymerase; $r p o \mathrm{~B}, \beta$-subunit of RNA polymerase; $r p o C_{1}, C_{2}, \beta^{\prime}$-subunit of RNA polymerase; and $r p s 4$, ribosomal protein $\mathrm{S}_{4}$.
}

change in DNA topology or (e) the combination of some of these factors. Therefore, the establishment of an appropriate in vitro transcription assay system is of prime importance to determine the decisive factor involved in regulating these changes.

Our recent experiments strongly suggest that transcriptional regulation is a decisive determinant of photosynthetic gene expression in the nonphotosynthetic plastids, amyloplasts of white sycamore cells $(29,31$, 34). In attempting to resolve the mechanisms operating therein, it was deemed to be of prime importance to establish the transcription system employing the DNAdependent RNA polymerase derived from plastid origin. It is known that higher plant plastids contain at least two different RNA polymerases, distinguishable from their specificity for particular genes as well as biochemical parameters $(15,36)$. Furthermore, a partially purified soluble RNA polymerase of plastid extracts was reported to contain all the necessary machineries for the correct transcription of structural genes $(25,41)$. Consequently, in order to determine the plastid DNA template activities and to explore a possible effect of soluble acting factor(s) in either amyloplasts or chloroplasts, 
we have employed the in vitro run-off transcription assay using the soluble plastid RNA polymerase.

Our previous studies have led us to suspect that the prime factor regulating plastid gene expression is likely to reside on the DNA template itself (31). Therefore, we have analyzed the differences in DNA templates obtained from both amyloplasts and chloroplasts. The consequence of DNA modification and/or rearrangement of the plastid genome at different developmental stages must be taken into account as a possible cause of changes in the overall transcriptional process. However, since we have found no structural rearrangements of DNA molecules between amyloplast and chloroplast genomes derived from the two different cell types of sycamore (30), other mechanisms of DNA modification must be sought. We have previously reported that the total amyloplast genome contains a variety of methylated bases in contrast to the chloroplast counterpart (31). In the present investigation, we have focused our attention on the methylated base contents of plastid DNA fragments containing specific genes.

\section{MATERIALS AND METHODS}

Plant cell culture. The white cell line of sycamore (Acer pseudoplatanus L.) was grown heterotrophically in a modified Lescure medium (3). The green cell line, originally selected by Lescure (24), was grown photomixotrophically under continuous illumination with fluorescent light $\left(15 \mu \mathrm{E} \cdot \mathrm{m}^{-2} \cdot \mathrm{sec}^{-1}\right)$ in the above medium without 2,4-D (34).

Preparation of intact plastids. Cells of the two sycamore lines harvested at the exponential growth stage were used immediately for isolating protoplasts. Intact amyloplasts (from white cells) and intact chloroplasts (from green cells) were isolated by discontinuous Percoll gradient centrifugation of the disrupted protoplasts as previously described (29).

Preparation of DNA and RNA. Highly purified closed-circular DNA was isolated from plastids by the repeated $\mathrm{CsCl}$ gradient centrifugation, first in the presence of ethidium bromide and then with Hoechst 33258 (Sigma) (29). Purified plastid DNA was ascertained to be free from contamination of nuclear DNA by Southern hybridization analysis using act and $r b c S$ gene probes. Total cellular RNA was also purified as reported previously (29).

Preparation of soluble plastid RNA polymerase. Soluble plastid RNA polymerase was prepared from intact chloroplasts or amyloplasts following the procedure described by Stirdivant et al. (41) with some modifications. Isolated plastids stored at $-80^{\circ} \mathrm{C}$ in $2 \mathrm{ml}$ of buffer containing $50 \mathrm{mM}$ Tris- $\mathrm{HCl}$ ( $\mathrm{pH} 8.0$ ), $10 \mathrm{mM} \mathrm{MgCl}_{2}, 40 \mathrm{mM}$ 2-mercaptoethanol, and $50 \mu \mathrm{g} / \mathrm{ml}$ of phenylmethylsulfonyl fluoride, were slowly thawed over a $150-\mathrm{min}$ period. A $0.5-\mathrm{ml}$ aliquot of $5 \times$ extraction buffer [ $20 \mathrm{mM}$ Tricine-KOH $(\mathrm{pH} 8.0), 2.5 \mathrm{M} \mathrm{KCl}$, and 1 $\mathrm{mM}$ dithiothreitol] was added to a $2-\mathrm{ml}$ mixture of the chloroplast lysate and stored in an ice bath for $10 \mathrm{~min}$ with occa- sional shaking. The plastid lysate was centrifuged at $12,000 \times$ $\mathrm{g}$ for $15 \mathrm{~min}$ at $4^{\circ} \mathrm{C}$. The supernatant fraction was kept in an ice bath, while the pellet was resuspended with $1 \times$ extraction buffer and recentrifuged to separate the supernatant. Supernatant fractions were combined and centrifuged at $225,000 \times \mathrm{g}$ for $30 \mathrm{~min}$ at $4^{\circ} \mathrm{C}$, and the clear supernatant obtained was adjusted to $3 \mathrm{mM} \mathrm{CaCl}_{2}$. Micrococcal nuclease (P-L Biochemicals) was added at a final concentration of 10 units $/ \mathrm{ml}$ to digest endogenous RNA. After incubation for $30 \mathrm{~min}$ at $0^{\circ} \mathrm{C}$, the nuclease reaction was terminated by the addition of $5 \mathrm{mM}$ ethyleneglycol-bis ( $\beta$-aminoethylether)- $N, N, N^{\prime}, N^{\prime}$-tetraacetic acid. The soluble plastid RNA polymerase obtained was used for in vitro transcription assays or stored with $50 \%$ glycerol at $-80^{\circ} \mathrm{C}$.

In vitro transcription assay. In vitro transcription assays of the closed-circular plastid DNA $(2 \mu \mathrm{g})$ using the soluble plastid RNA polymerase was performed in the presence of $[\alpha-$ $\left.{ }^{32} \mathrm{P}\right] \mathrm{UTP}$ and a RNase-inhibitor from human placenta (Takara); the purification procedure of the labeled transcripts has been described previously (31). To determine the incorporation of $\left[\alpha^{-}{ }^{32} \mathrm{P}\right] \mathrm{UTP}$ into RNA, an aliquot of the purified transcripts was subjected to liquid scintillation spectrometry. The labeled transcripts were subjected to hybridization analysis with either EcoRI-digested amyloplast DNA or specific gene probes on a Zeta-Probe membrane (Bio-Rad). DNARNA hybridization was performed with the labeled transcripts as described (31).

Size analysis of in vitro transcription products. Nonlabeled transcripts were produced using the in vitro transcription assay system, as described above, in the presence of nonradioactive UTP. To compare the sizes of transcripts, both the in vitro transcripts and total cellular RNA were denatured with glyoxal and subjected to electrophoresis in a $1.2 \%$ agarose gel, followed by RNA-DNA hybridization using the labeled DNA probes (29).

$D N A$ probes. To identify the specific plastid genes and their transcripts, the plasmids containing maize chloroplast DNA sequences were used throughout this investigation: pZmc461 for the RuBisCO large subunit ( $r b c \mathrm{~L}$ ) and pZmc427 for the $32-\mathrm{kDa} \mathrm{D}_{1}$ protein $(p s b \mathrm{~A})(22,23)$. To determine the contamination of nuclear DNA in plastid DNA preparations, plasmids bearing pea leaf cDNA clones for $r b c S(p S S 15)$ (5) and synthetic oligonucleotides complementary to conserved sequences of the act gene of dicotyledonous origin (33) were used for hybridization. DNA probes were labeled with $[\alpha-$ $\left.{ }^{32} \mathrm{P}\right] \mathrm{d}$ CTP using the Klenow fragment of $E$. coli DNA polymerase $\mathrm{I}$ and primers in Oligolabelling Kit (Pharmacia, Uppsala). Oligonucleotide probes were labeled at the 3 '-end by $\mathrm{T} 4$ polynucleotide kinase with $\left[\gamma^{-32} \mathrm{P}\right] \mathrm{ATP}$. No hybridization between plastid DNA molecules and plasmid vectors, pBR322 and its derivatives was obtained.

Determination of DNA base composition. Highly purified chloroplast and amyloplast DNA, as mentioned above, were digested with either EcoRI (E) or HindIII (H) and electrophoresed in an agarose gel L03 (Takara). Specific DNA 
fragments were purified from the gel using the Geneclean Kit from BIO 101. Purified DNA was hydrolyzed in a sealed glass tube with $90 \%(\mathrm{v} / \mathrm{v})$ formic acid $\left(1 \mu \mathrm{l} / \mu \mathrm{g}\right.$ of DNA) at $175^{\circ} \mathrm{C}$ for $30 \mathrm{~min}$ and subjected to analysis of the base composition by reversed-phase HPLC as described previously (31).

\section{RESULTS}

Low template activity of amyloplast DNA in in vitro transcription assays. To elucidate the mechanisms governing transcriptional regulation of photosynthetic gene expression in amyloplasts, we have examined the template activity of amyloplast DNA in comparison with the chloroplast counterpart, employing an in vitro transcription assay system containing the soluble plastid RNA polymerase. In these experiments, the following reactions were carried out: (a) chloroplast extracts with amyloplast DNA template and (b) amyloplast extracts with chloroplast DNA templates in addition to the homologous reactions. The soluble plastid RNA polymerase used has been reported to contain all components required for correct transcription of the genes coding for mRNAs $(25,41)$. The reaction was carried out using $\left[\alpha^{32} \mathrm{P}\right] \mathrm{UTP}$ as a substrate and radioactivity incorporated into the RNA fraction was determined. As shown in Table I, the template activity of amyloplast DNA for either chloroplast or amyloplast extracts was about $1.5 \%$ of that of the chloroplast DNA. Interestingly, the template activity was indistinguishable regardless of which plastid extract was used. Furthermore, the incorporation of ${ }^{32} \mathrm{P}$ was barely detectable in the RNA fraction without addition of an exogenous DNA template, suggesting that neither plastid extract was contaminated by endogenous DNA.

The hybridization of in vitro transcripts to the amyloplast genome shown in Fig. 1 indicates the relative transcriptional activity of genes located in each restriction fragment. The hybridization profiles were nearly identical when the same DNA template was subjected to the

Table I. Template activities of Chloroplast and AMYLOPLAST DNA IN in vitro RUN-OFF TRANSCRIPTION ASSAY.

\begin{tabular}{|c|c|c|}
\hline $\begin{array}{l}\text { DNA } \\
\text { templates }\end{array}$ & $\begin{array}{c}\text { Extracts } \\
\text { (RNA polymerase) }\end{array}$ & $\begin{array}{l}{ }^{32} \mathrm{P} \text { incorporated } \\
\text { into RNA fractions } \\
\text { (cpm/reaction) }\end{array}$ \\
\hline \multirow[t]{2}{*}{ None } & Chloroplast & 77.6 \\
\hline & Amyloplast & 81.0 \\
\hline \multirow[t]{2}{*}{ Chloroplast } & Chloroplast & $684 \times 10^{5}$ \\
\hline & Amyloplast & $666 \times 10^{5}$ \\
\hline \multirow[t]{2}{*}{ Amyloplast } & Chloroplast & $11.2 \times 10^{5}$ \\
\hline & Amyloplast & $10.0 \times 10^{5}$ \\
\hline
\end{tabular}

${ }^{a}$ Highly purified DNA ( $\left.2 \mu \mathrm{g}\right)$ from intact plastids of green or white cultured-cells of sycamore were subjected to in vitro transcription assays using extract (RNA polymerase) from either chloroplasts or amyloplasts as described in MATERIALS AND METHODS. in vitro transcription assay using either chloroplast $\left(\mathrm{C}_{t}\right)$ or amyloplast (A) extract (lanes 2 and 3, chloroplast DNA; lanes 4 and 5, amyloplast DNA). However, a marked difference was observed between the hybridization pattern of messengers derived from the chloroplast DNA template compared to those derived from amyloplast DNA.

The results lead us to the following conclusions: (a) the factors present in amyloplast extract do not inhibit transcription of chloroplast DNA, and the factors present in the chloroplast extract do not promote transcription of the amyloplast DNA, and (b) most of the amylo-

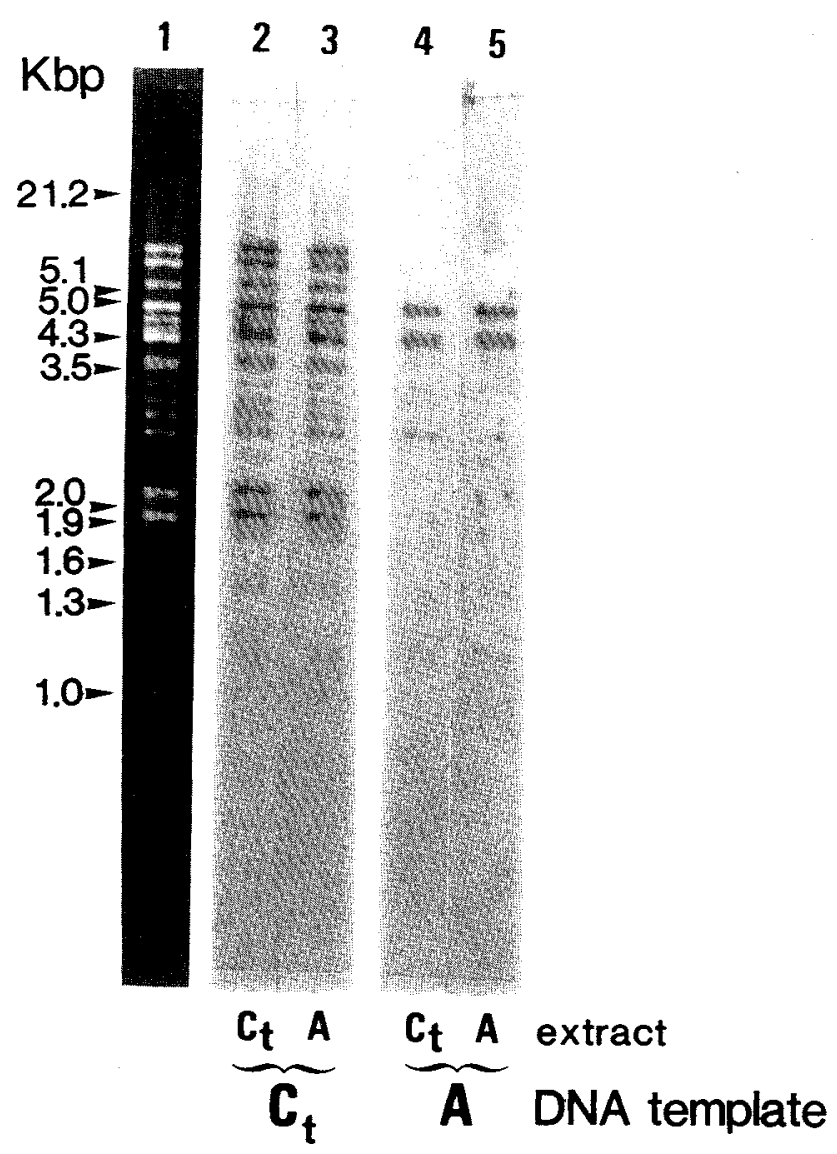

Fig. 1. Hybridization of restricted amyloplast DNA with $\left[{ }^{32} \mathrm{P}\right]$ labeled in vitro transcripts.

Purified ${ }^{32} \mathrm{P}$-labeled RNA isolated from in vitro transcription assays containing chloroplast $\left(\mathrm{C}_{\mathrm{t}}\right)$ or amyloplast (A) DNA templates and soluble RNA polymerase from chloroplasts or amyloplasts were hybridized with EcoRI-digested amyloplast DNA (5 g/lane). Lane 1: ethidium bromide-staining EcoRI-digested amyloplast DNA. Lanes 2 and 3: hybridization with ${ }^{32} \mathrm{P}$-labeled RNA products obtained from the in vitro transcription of chloroplast DNA template using chloroplast and amyloplast extracts, respectively. Lanes 4 and 5: hybridization with ${ }^{32} \mathrm{P}$-labeled RNA products obtained from the in vitro transcription of amyloplast DNA template using chloroplast and amyloplast extracts, respectively. 
plast DNA regions cannot serve as templates for transcription. It will be emphasized that these implications are consistent with the results of our previous investigations, suggesting that the transcription of photosynthetic genes in amyloplasts derived from the white sycamore cells is suppressed $(29,31,34)$. Different relative template activities of the amyloplast and chloroplast DNAs are similar to those obtained from the plastid run-on transcription system (34). Therefore, it is highly conceivable that the template activity of amyloplast DNA per se appears to be the element modulating transcriptional activity of the organelle.

We have further examined the in vitro transcription using $r b c \mathrm{~L}$ and $p s b \mathrm{~A}$. The radioactive transcripts were subjected to hybridization with the cloned chloroplast $r b c \mathrm{~L}$ and $p s b \mathrm{~A}$ genes (data not shown). Both $r b c \mathrm{~L}$ and $p s b \mathrm{~A}$ in the chloroplast genome served well as the template in the in vitro transcription assay using either amyloplast or chloroplast extracts. In contrast, $p s b \mathrm{~A}$ in the amyloplast genome served well as the template in the in vitro transcription assay using either one of the two plastid extracts, although $r b c \mathrm{~L}$ did not. These results are consistent with the abundance of specific genes including $r b c \mathrm{~L}$ and $p s b \mathrm{~A}$ mRNA in both green and white cells of sycamore, as reported previously (29).

Hybridization with the total plastid DNA (Fig. 1) or the plasmids containing specific gene sequences precludes the detection of transcripts from the individual genes especially when more than one gene or polycistronic transcription units are located closely adjacent to each other. In order to assure that the in vitro transcription is initiated from the correct promoter site, sizes of the unlabeled in vitro transcripts were compared with those of the transcripts in the total cellular RNA obtained from both cell lines of sycamore. As shown in Fig. 2, hybridization of chloroplast $r b c \mathrm{~L}$ (A) and $p s b \mathrm{~A}(\mathrm{~B})$ gene probes to RNAs from either white and green cells (lanes 1 and 2) or the six in vitro transcription reactions (lanes 3-8) clearly indicate that the sizes of transcripts from the total cellular RNA as well as the in vitro transcription system are nearly identical, approximately 1.6 kilobases $(\mathrm{kb})$ for $r b c \mathrm{~L}$ and $1.2 \mathrm{~kb}$ for $p s b \mathrm{~A}$, respectively. No signals were detectable in the absence of exogenous DNA added to the transcription assay mixture (lanes 3 and 6), indicating that the detected bands are really the in vitro transcripts rather than the endogenous RNA. Transcripts for $r b c \mathrm{~L}$ were not detectable in either the cellular RNA of white cells (lane 1) or the in vitro products from the amyloplast DNA template by RNA polymerase activity in chloroplast (lane 5) or amyloplast (lane 8) extracts. However, the presence of transcripts from psbA (lane 1,5 and 8) indicates that this gene is actively transcribed in amyloplasts. The data in Fig. 2 also indicate that transcriptional initiation and termination occur at the correct positions in both in vitro transcription assay systems containing plastid extracts. The sizes of transcripts for $r b c \mathrm{~L}$ and $p s b \mathrm{~A}$ were nearly identical with those reported in several other plant species $(12,42)$. All these experimental data strongly support that both $r b c \mathrm{~L}$ and $p s b \mathrm{~A}$ are transcribed by their own promoter but not upstream promoters as read-through transcription.

Methylated bases are present only in the suppressed gene regions of amyloplast genome. Highly purified plastid DNA fragments were completely hydrolyzed and subjected to base composition analyses by reversedphase HPLC. The mol\% of the base composition was calculated by standardization of each peak area with respect to the authentic bases (Tables II and III). The $H$ indIII restriction fragments of the plastid genome contain the following genes (Fig. 3): psbA region ( $p s b \mathrm{~A})$; rDNA region (16S rDNA); and the suppressed region

\section{8}

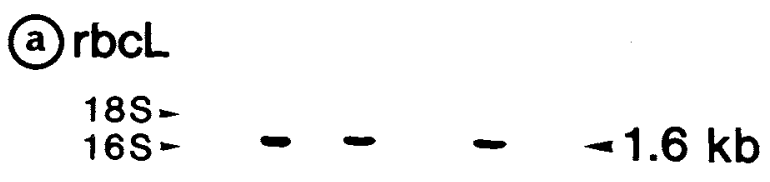

\section{(b)psbA}

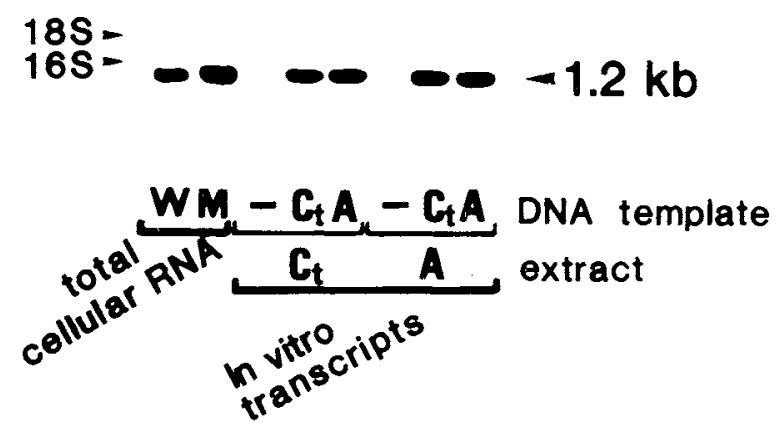

Fig. 2. Size determination of transcripts for $r b c \mathrm{~L}$ and $p s b \mathrm{~A}$ in total cellular RNA and in vitro transcripts.

Two $\mu \mathrm{g}$ of total cellular RNA from white (W) and green (M) cells was applied on lanes 1 and 2, respectively. Nonradioactive RNA isolated from in vitro transcription in the absence of DNA template $(-)$ and the presence of chloroplast $\left(\mathrm{C}_{t}\right)$ or amyloplast (A) DNA template using soluble RNA polymerase from chloroplasts (lanes 3-5, respectively) or amyloplasts (lanes $6-8$, respectively) with unlabeled UTP instead of $\left[\alpha-{ }^{32} \mathrm{P}\right] \mathrm{UTP}$ were analyzed. Hybridization was performed with the following chloroplast gene probes labeled with ${ }^{32} \mathrm{P}$ : panel a, $r b c \mathrm{~L}$ and panel $\mathrm{b}, p s b \mathrm{~A}$. The estimated sizes of the transcripts are indicated at the right in kilobases $(\mathrm{kb})$, and the positions of size markers, $18 \mathrm{~S}$ rRNA of Hela cells and 16S rRNA of E. coli, are presented at the left. 
Table II. Distribution of modified bases In amyloplast (A) AND Chloroplast $\left(C_{i}\right)$ DNA.

\begin{tabular}{|c|c|c|c|c|c|c|c|c|c|c|c|c|c|}
\hline \multirow{3}{*}{ DNA fragment ${ }^{a}$} & & \multicolumn{12}{|c|}{ Base compositions (mol\%) } \\
\hline & & \multicolumn{3}{|c|}{ Cytosine } & \multicolumn{5}{|c|}{ Guanine } & \multicolumn{3}{|c|}{ Adenine } & \multirow{2}{*}{$\frac{\text { Thymine }}{\mathrm{T}}$} \\
\hline & & $\mathrm{C}$ & $3 \mathrm{mC}$ & $5 \mathrm{mC}$ & $\mathrm{G}$ & $1 \mathrm{mG}$ & $3 \mathrm{mG}$ & $7 \mathrm{mG}$ & $\mathrm{NmG}$ & A & $1 \mathrm{~mA}$ & $\mathrm{NmA}$ & \\
\hline \multirow[t]{2}{*}{ Total } & A & 11.79 & 1.45 & 4.79 & 16.96 & $\mathrm{n} . \mathrm{d}^{\mathrm{c}}$ & n.d. & 1.09 & 1.19 & 30.42 & n.d. & 1.42 & 30.89 \\
\hline & $\mathrm{C}_{\mathrm{t}}$ & 18.54 & 0.12 & n.d. & 18.71 & n.d. & n.d. & n.d. & n.d. & 31.05 & n.d. & n.d. & 31.58 \\
\hline \multirow[t]{2}{*}{$p s b \mathrm{~A}$ region } & A & 18.98 & n.d. & n.d. & 18.94 & n.d. & n.d. & 0.03 & 0.02 & 30.94 & n.d. & n.d. & 31.09 \\
\hline & $\mathrm{C}_{\mathrm{t}}$ & 19.00 & n.d. & n.d. & 18.96 & n.d. & n.d. & n.d. & n.d. & 31.01 & n.d. & n.d. & 31.03 \\
\hline \multirow[t]{2}{*}{ rDNA region } & A & 21.85 & n.d. & n.d. & 21.64 & n.d. & n.d. & 0.05 & 0.04 & 28.34 & n.d. & n.d. & 28.08 \\
\hline & $\mathrm{C}_{\mathrm{t}}$ & 21.79 & n.d. & n.d. & 21.75 & n.d. & n.d. & n.d. & n.d. & 28.41 & n.d. & n.d. & 28.05 \\
\hline \multirow[t]{2}{*}{ Suppressed region } & A & 8.41 & 2.01 & 7.84 & 14.57 & n.d. & n.d. & 1.74 & 1.90 & 29.60 & n.d. & 2.24 & 31.69 \\
\hline & $\mathrm{C}_{\mathrm{t}}$ & 18.59 & 0.21 & n.d. & 18.76 & n.d. & n.d. & n.d. & n.d. & 31.49 & n.d. & n.d. & 30.95 \\
\hline
\end{tabular}

a The restriction map and location of genes in the plastid genome are described in the previous report (30): the psbA region contains $\mathrm{H} 4$ and $\mathrm{H} 10$ fragments; rDNA region contains $\mathrm{H} 7, \mathrm{H} 8, \mathrm{H} 9 \mathrm{a}, \mathrm{H} 9 \mathrm{~b}, \mathrm{H} 11, \mathrm{H} 12, \mathrm{H} 13$, and $\mathrm{H} 14$ fragments; and the suppressed region contains $\mathrm{H} 1, \mathrm{H} 2$, $\mathrm{H} 3 \mathrm{a}, \mathrm{H} 3 \mathrm{~b}, \mathrm{H} 5, \mathrm{H} 6, \mathrm{H15}$, and H16 fragments. Relevant DNA regions are indicated in Figure 3.

b The mol\% values were calculated by standardization of the 254-nm absorbance of the elution peak area employing standard mixtures of 4 major bases and 8 methylated ones (cf. Figure 3 in reference 31). Acid hydrolysates of DNA ( $500 \mathrm{ng}$ ) were subjected to the HPLC analysis, and the results are the averages of two separate determinations. C, cytosine; 3mC, 3-methylcytosine; 5mC, 5 -methylcytosine; G, Guanine; $1 \mathrm{mG}, 1$ methylguanine; 3mG, 3-methylguanine; $7 \mathrm{mG}, 7$-methylguanine; $\mathrm{NmG}, N^{2}$-methylguanine; A, adenine; 1mA, 1-methyladenine; NmA, $N^{6}$-methyladenine; and $\mathrm{T}$, thymine.

c Not detectable, less than $0.02 \%$.

$\left(r p o \mathrm{~A}, r b c \mathrm{~L}, a t p \mathrm{~B}, \mathrm{E}, r p s 4, p s a \mathrm{~A}, r p o \mathrm{~B}, r p o \mathrm{C}_{2}\right.$, and atp A). A variety of modified bases, including 3-methylcytosine, 5-methylcytosine, 7-methylguanine, $N^{2}$-meth- ylguanine, and $N^{6}$-methyladenine were present in the amyloplast DNA in contrast to the almost total absence of methylated bases in the chloroplast DNA (Table II

Table III. Distribution of modified bases in amyloplast (A) and Chloroplast $\left(C_{t}\right)$ DNA fRagments CONTAining SPECific Genes.

\begin{tabular}{|c|c|c|c|c|c|c|c|c|c|c|c|c|c|}
\hline \multirow{3}{*}{ DNA fragment ${ }^{a}$} & & \multicolumn{12}{|c|}{ Base compositions $(\mathrm{mol} \%)^{\mathrm{b}}$} \\
\hline & & \multicolumn{3}{|c|}{ Cytosine } & \multicolumn{5}{|c|}{ Guanine } & \multicolumn{3}{|c|}{ Adenine } & \multirow{2}{*}{$\frac{\text { Thymine }}{\mathbf{T}}$} \\
\hline & & $\mathrm{C}$ & $3 \mathrm{mC}$ & $5 \mathrm{mC}$ & $\mathrm{G}$ & $1 \mathrm{mG}$ & $3 \mathrm{mG}$ & $7 \mathrm{mG}$ & $\mathrm{NmG}$ & A & $1 \mathrm{~mA}$ & $\mathrm{NmA}$ & \\
\hline \multirow[t]{2}{*}{$p s b \mathrm{~A}$} & A & 19.01 & $n \cdot d^{c}$ & n.d. & 18.96 & n.d. & n.d. & n.d. & n.d. & 31.02 & n.d. & n.d. & 31.01 \\
\hline & $\mathrm{C}_{\mathrm{t}}$ & 19.02 & n.d. & n.d. & 18.96 & n.d. & n.d. & n.d. & n.d. & 31.03 & n.d. & n.d. & 30.99 \\
\hline \multirow[t]{2}{*}{$16 \mathrm{~S}$ rDNA } & A & 20.81 & n.d. & n.d. & 20.91 & n.d. & n.d. & n.d. & n.d. & 29.13 & n.d. & n.d. & 29.15 \\
\hline & $\mathrm{C}_{\mathrm{t}}$ & 20.78 & n.d. & n.d. & 20.86 & n.d. & n.d. & n.d. & n.d. & 29.17 & n.d. & n.d. & 29.19 \\
\hline \multirow[t]{2}{*}{$r b c \mathrm{~L}$} & A & 16.70 & 0.08 & 3.07 & 18.69 & n.d. & n.d. & 0.49 & 0.70 & 30.12 & n.d. & n.d. & 30.15 \\
\hline & $\mathrm{C}_{\mathrm{t}}$ & 19.87 & n.d. & n.d. & 19.91 & n.d. & n.d. & n.d. & n.d. & 30.09 & n.d. & n.d. & 30.13 \\
\hline \multirow[t]{2}{*}{$\operatorname{atp} \mathrm{B}, \mathrm{E} ; r p o \mathrm{C}_{2}$} & $\mathrm{~A}$ & 19.82 & n.d. & 3.03 & 22.34 & n.d. & n.d. & 0.18 & 0.45 & 26.80 & n.d. & 0.34 & 27.04 \\
\hline & $\mathrm{C}_{\mathrm{t}}$ & 22.87 & n.d. & n.d. & 22.94 & n.d. & n.d. & n.d. & n.d. & 27.10 & n.d. & n.d. & 27.09 \\
\hline \multirow[t]{2}{*}{$r p s 4$} & A & 21.10 & n.d. & 2.99 & 23.16 & n.d. & n.d. & 0.56 & 0.22 & 25.93 & n.d. & 0.15 & 25.98 \\
\hline & $\mathrm{C}_{\mathrm{t}}$ & 23.86 & n.d. & n.d. & 23.92 & n.d. & n.d. & n.d. & n.d. & 26.10 & n.d. & n.d. & 26.12 \\
\hline \multirow[t]{2}{*}{$p s a \mathrm{~A}$} & A & 14.71 & 0.03 & 3.69 & 18.49 & n.d. & n.d. & 0.05 & n.d. & 31.53 & n.d. & n.d. & 31.50 \\
\hline & $C_{t}$ & 18.47 & n.d. & n.d. & 18.56 & n.d. & n.d. & n.d. & n.d. & 31.49 & n.d. & n.d. & 31.48 \\
\hline \multirow[t]{2}{*}{$\operatorname{atpA}$} & $\mathrm{A}$ & 21.45 & n.d. & 3.12 & 24.50 & n.d. & n.d. & 0.08 & n.d. & 24.86 & n.d. & 0.60 & 25.39 \\
\hline & $\mathrm{C}_{\mathrm{t}}$ & 24.56 & n.d. & n.d. & 24.53 & n.d. & n.d. & n.d. & n.d. & 25.48 & n.d. & n.d. & 25.43 \\
\hline
\end{tabular}

a The restriction map and location of genes in the plastid genome are described in the the previous report (30): $p s b \mathrm{~A}$ (E6 fragment): 16S rDNA (E8a and $\mathrm{E} 8 \mathrm{~b}$ fragments); $r b c \mathrm{~L}$ (E9 fragment); $a t p \mathrm{~B}, \mathrm{E}$ and $r p o \mathrm{C}_{2}$ (E10a and $\mathrm{E} 10 \mathrm{~b}$ fragments); $r p s 4$ (E5 fragment); $p s a \mathrm{~A}$ (E2 fragment); and atpA (E3 fragment).

b The mol\% values were calculated by standardization of the 254-nm absorbance of the elution peak area employing standard mixtures of 4 major bases and 8 methylated ones (cf. Figure 3 in reference 31). Acid hydrolysates of DNA (500 ng) were subjected to the HPLC analysis, and the results are the averages of two separate determinations. C, cytosine; 3mC, 3-methylcytosine; 5mC, 5-methylcytosine; G, guanine; $1 \mathrm{mG}, 1$ methylguanine; $3 \mathrm{mG}, 3$-methylguanine; $7 \mathrm{mG}, 7$-methylguanine; NmG, $N^{2}$-methylguanine; A, adenine; $1 \mathrm{~mA}, 1$-methyladenine; NmA, $N^{6}$-methyladenine; and $\mathrm{T}$, thymine.

c Not detectable, less than $0.02 \%$. 


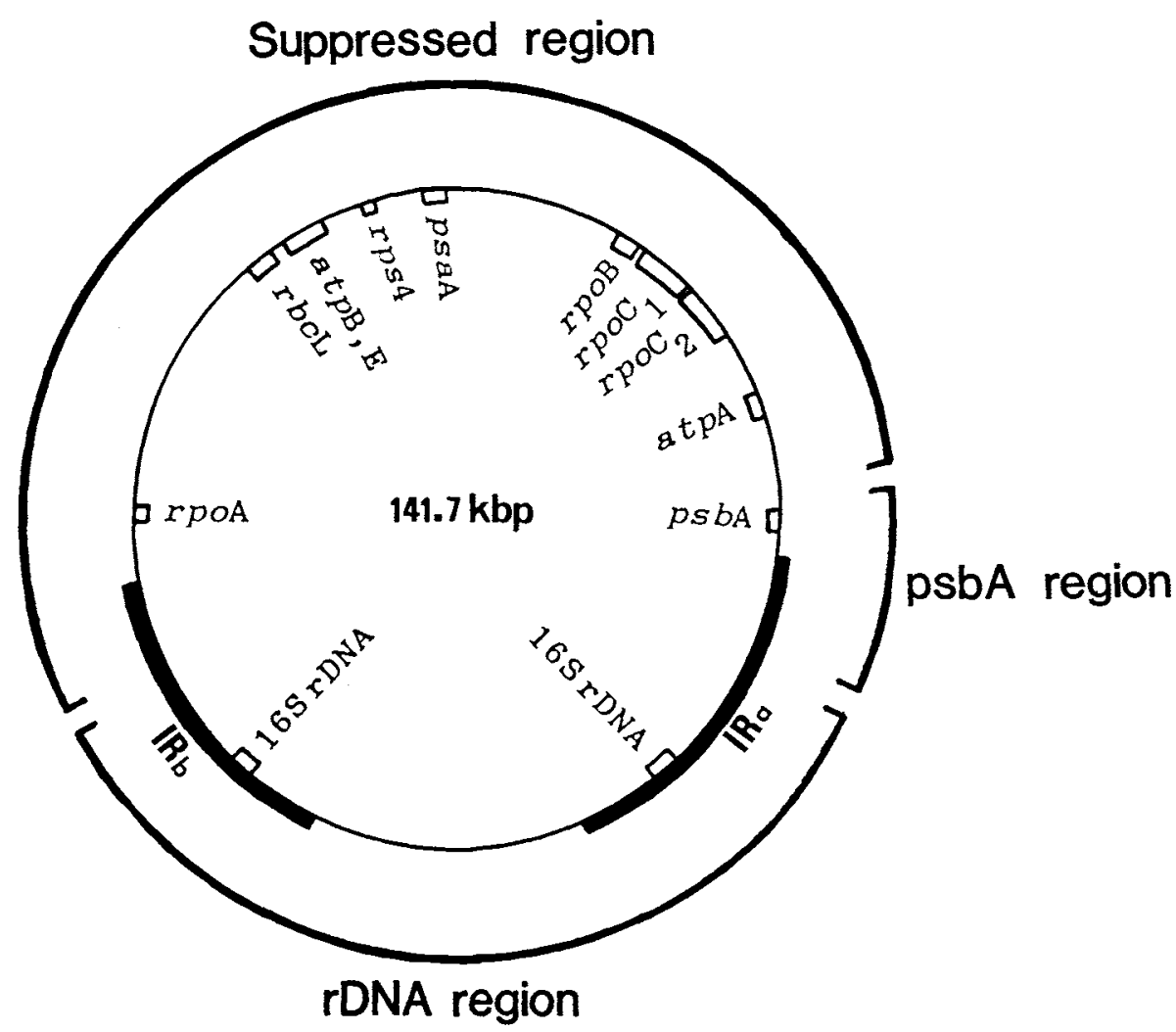

Fig. 3. Gene map of plastid genome of sycamore (141.7 kbp).

The inner circle indicates the location of genes inferred from the hybridization of restriction fragments of sycamore amyloplast DNA with gene probes from maize and tobacco chloroplast DNA (cf. 30). Regions of inverted repeat are indicated by the solid segments, IR $a$ and $I_{R_{b}}$. The outer circle, three bold lines, represent the $p s b$ A region, rDNA region and the suppressed region (see the note to Table II) which were subjected to the base composition analyses as presented in Table II.

and ref. 31). 5-methylcytosine was found to be the most abundantly present, accounting for $4.79 \%$ of the total base residues in the amyloplast genome. The analysis of methylated bases clearly shows that methylation occurs only in the suppressed region of the amyloplast DNA, whereas it is barely detectable in the $p s b \mathrm{~A}$ and rDNA regions of the amyloplast DNA. As mentioned before, methylation is scarcely detectable in the chloroplast DNA. It must be noted that the content of 5-methylcytosine accounts for $7.84 \%$ of the total base residues in the suppressed region of amyloplast DNA.

We have extended our analysis to determine the content of the methylated bases more precisely using DNA fragments containing the specific genes. EcoRI fragments containing individual genes were then subjected to HPLC analysis. As presented in Table III, a variety of methylated bases, especially 5-methylcytosine, were detected only in the DNA fragments containing the suppressed genes of the amyloplast genome such as $r b c \mathrm{~L}$, $a t p \mathrm{~B}, \mathrm{E}, r p s 4, p s a \mathrm{~A}$ and $a t p \mathrm{~A}$, although they were not detectable in DNA fragments containing the expressed genes such as $p s b \mathrm{~A}$ and $16 \mathrm{~S}$ rDNA. Methylation was also undetectable in the entire chloroplast genome. These results strongly suggest that methylated bases, especially 5-methylcytosine, are involved in the suppression of photosynthetic genes in the amyloplast genome.

\section{DISCUSSION}

Our findings based on experiments using the cultured cells of sycamore indicate that transcriptional regulation is responsible for suppression of photosynthetic genes in amyloplasts of the nonphotosynthetic white cell line $(29,31,34)$. This has prompted us to study the suppression mechanism in more detail. In order to determine the template activities of amyloplast or chloroplast DNA, we have employed in vitro run-off transcription systems using the plastid extracts containing soluble RNA polymerase and other factors necessary for transcription (41). Thus we can elucidate whether or not acting factor(s) possibly present in the soluble plastid extracts could be responsible for the transcriptional regulation of the amyloplast genome in comparison with the chloroplast genome. The results obtained clearly show 
that most amyloplast DNA regions cannot serve as the template for transcription and that trans-acting or $\sigma$ like factors do not appear to be directly involved in the suppression of these gene regions. Therefore, we tend to postulate that the template activity of the amyloplast genome primarily modulates transcriptional activity. Interestingly, from the fact that the correct transcription and processing have been found to operate for $p s b \mathrm{~A}$ by the amyloplast extracts, transcriptional machinery is thought to be functional in this nonphotosynthetic plastid.

It is likely that DNA template activities depend on the molecular structure of DNA. Previously, we compared the restriction endonuclease digestion patterns (31), as well as the localization of specific genes in the digested DNA fragments by Southern hybridization (30), and found that the patterns were indistinguishable. These results suggest that there is no rearrangement between amyloplast and chloroplast genomes comparable to that reported with the chloroplast/chromoplast genome system of ripening fruits $(14,32)$. Evidently there must be other modes of DNA modification. Our previous studies have demonstrated that a variety of methylated bases, especially 5-methylcytosine, is abundant in amyloplast DNA in comparison to the chloroplast counterpart (31). Additionally, our experiments dealing with methylated base sequences in amyloplast DNA employing a pair of methyl-sensitive and -insensitive isoschizomeric endonucleases have shown that the methylated sequences are not detectable in any region of chloroplast DNA, or in regions of amyloplast DNA containing actively expressed genes: e.g., psbA and $16 \mathrm{~S}$ rDNA. In contrast, we found that DNA fragments containing barely transcribed genes, e.g., $r b c \mathrm{~L}$, atp $\mathrm{A}$, $a t p \mathrm{~B}, \mathrm{E}, p s a \mathrm{~A}$ and $r p s 4$, are heavily methylated (31).

In view of the fact that only specific DNA sequences can be recognized by the methyl-sensitive restriction endonuclease, it may be argued that the failure to find methylated sequences is simply due to the inability of the endonuclease(s) to discriminate relevant sites. In order to circumvent the inherent weakness of this method, we have analyzed the content of methylated bases in the specific DNA fragments containing individual genes, the transcriptional activities of which are known. Taken together, our results show that a variety of methylated bases present in the total amyloplast genome are specifically localized in the regions containing the suppressed genes. In contrast, methylation is absent in the actively expressed gene regions of the amyloplast genome, as well as in all regions of the chloroplast genome.

The basic mechanism for regulating transcriptional process consists of a complicated network of proteinDNA interactions. Clearly, the binding of RNA polymerase with DNA templates is the first essential step of transcription. However, it has long been hypothesized that DNA methylation not only interferes with the protein-DNA interactions but may also alter the overall structure of a gene (20). Therefore, it is tempting to postulate that (a) DNA methylation may interfere with the binding of protein factor(s) at discrete cis-acting regions required for the transcriptional activity, (b) DNA methylation at the promoter region prevents binding of RNA polymerase, (c) DNA methylation of the coding region of the gene acts to inhibit the elongation step of the RNA polymerase reaction, and (d) DNA methylation affects the local structure of chromatin causing an inactive conformation.

It has been reported that the transcriptional activities of certain vertebrate genes are correlated with reduced levels of methylation (for reviews, see refs. 6, 9, 10, 16, 38 ) and 5-methylcytosine was shown to be present in the DNA of all the vertebrates and higher plant cells (11, $13,39)$. The content of 5-methylcytosine in plant DNAs is generally much higher than in vertebrates. As much as one-third of the total cytosine residues in plants are methylated (39), generally appearing as $\mathrm{CpNpG}$ and CpG sequences (16). A good deal of experimental evidence has shown that methylation of certain $\mathrm{CpG}$ sites in vertebrate DNA controls gene expression $(2,9,38$, 43). Plant DNA methylation may have a similar function (for recent examples, see refs. 1, 19, 27, 37, 40, 44), as well as other functions such as the suppression of movement of transposable elements $(7,8,26)$. It must be emphasized that methylated DNA is not generally detectable in the photosynthetically active chloroplasts, except for the green alga Chlamydomonas reinhardtil (4).

From the results obtained in this investigation together with our previous reports $(29,31,34)$, it is conceivable that amyloplast DNA is selectively methylated, resulting in the suppression of some photosynthetic genes. Interference with recognition and/or binding of RNA polymerase with methylated regions of DNA could be the mechanism of suppression. However, in order to obtain a definite answer to this intriguing mechanism of transcriptional regulation, it is evidently necessary to characterize the key species of modified bases and their precise location in the gene sequence.

Independently, we have demonstrated that DNA methylation is probably responsible for the suppression of nuclear-encoded photosynthetic genes in the nonphotosynthetic white-wild cell line of sycamore (33), as well as that of plastid-encoded photosynthetic genes in a naturally occurring nonphotosynthetic plastid type, chromoplasts, in ripening tomato fruits $(21,32)$. This mechanism also appears to govern the differential expression of $r b c \mathrm{~L}$ in the two cell types of greening maize seedlings (35). 
Acknowledgements. We are grateful to Dr. L. Bogorad (Harvard University) and Dr. N.-H. Chua (Rockefeller University) for the gift of plasmids containing the specific gene probes used in this investigation. This is paper No. (85) in the series "Structure and Function of Chloroplast Proteins". The research was supported by Grants-in-Aid from the Ministry of Education, Science and Culture of Japan (Monbusho) and the Nissan Science Foundation (Tokyo). J.N. expresses her thanks to the Hitachi Scholarship Foundation (Tokyo) for the predoctoral scholarship.

\section{REFERENCES}

1. Amasino, R.M., Powell, A.L.T., and Gordon, M.P. (1984). Changes in T-DNA methylation and expression are associated with phenotypic variation and plant regeneration in a crown gall tumor line. Mol. Gen. Genet. 197: 437-446.

2. Bianchi, N.O., Peltomaki, P., Bianchi, M.S., KnuUtila, S., and DE LA CHAPELle, A. (1988). Demethylation of two specific DNA sequences in expressed human immunoglobulin light kappa constant genes. Somatic Cell Mol. Genet. 14: 13-20.

3. Bligny, R. and Leguay, J.J. (1987). Techniques of cell suspension culture. Meth. Enzymol. 148: 3-16.

4. Bolen, P.L., Grant, D.M., Swinton, D., Boynton, J.E., and Gillham, N.W. (1982). Extensive methylation of chloroplast DNA by a nuclear gene mutation does not affect chloroplast gene transmission in Chlamydomonas. Cell 28: 3351-343.

5. Broglie, R., Bellemare, G., Bartlett, S.G., Chua, N.-H., and CASHMORe, A.R. (1981). Cloned DNA sequences complementary to mRNAs encoding precursors to the small subunit of ribulose-1, 5-bisphosphate carboxylase and a chlorophyll $a / b$ binding polypeptide. Proc. Natl. Acad. Sci. USA 78: 73047308.

6. CeDAR, H. (1988). DNA methylation and gene activity. Cell 53: 3-4.

7. Chandler, V.L. and Walbot, V. (1986). DNA modification of a maize transposable element correlates with loss of activity. Proc. Natl. Acad. Sci. USA 83: 1767-1771.

8. Chomet, P.S., Wessler, S., and Dellaporta, S.L. (1987). Inactivation of the maize transposable element activator $(A c)$ is associated with its DNA modification. EMBO. J. 6: 295-302.

9. DoErfler, W. (1983). DNA methylation and gene activity. Ann. Rev. Biochem. 52: 93-124.

10. DYNAN, W.S. (1989). Understanding the molecular mechanism by which methylation influences gene expression. Trends Genet. 5: 35-36.

11. Ehrlion, M. and Wang, R.Y.H. (1981). 5-Methylcytosine in eukaryotic DNA. Science 212: 1350-1357.

12. ERION, J.L. (1985). Characterization of the mRNA transcripts of the maize, ribulose-1, 5-bisphosphate carboxylase, large subunit gene. Plant Mol. Biol. 4: 169-179.

13. Gama-Sosa, M.A., Midgeft, R., Slagal, V.A., Githens, S., Kuo, K.C., GehrKe, C.W., and Ehrich, M. (1983). Tissuespecific differences in DNA methylation in various mammals. Biochim. Biophys. Acta 740: 212-219.

14. Gounaris, I., Michialowski, C.B., Bohnert, H.J., and Price, C.A. (1986). Restriction and gene maps of plastid DNA from Capsicum annuum. Curr. Genet. 11: 7-16.

15. Greenberg, B.M., Narita, J.O., Delucal-Flaherty, C.R., and Hallick, R.B. (1985). Properties of chloroplast RNA polymerase. In Molecular Biology of the Photosynthetic Apparatus (K.E. Steinback, S. Bonity, C.J. Arntzen, and L. Bogorad, eds.) Cold Spring Harbor Laboratory. pp. 303-309.
16. Gruenbaum, Y.T., Naveh-Many, H., Cedar, H., and Razin, A. (1981). Sequence specificity of methylation in higher plant DNA. Nature 292: 860-862.

17. Gruissem, W. (1989). Chloroplast gene expression: how plants turn their plastids on. Cell 56: 161-170.

18. Gruissem, W., Barkan, A., Deng, X.W., and Stern, D. (1988). Transcriptional and post-transcriptional control of plastid mRNA levels in higher plants. Trends Genet, 4: 758763.

19. Hepburn, A.G., Belange, F.C., and Mattheis, J.R. (1987). DNA methylation in plants. Dev. Genet. 8: 475-493.

20. Keshet, I., Lieman-Hurwitz, J., and Cedar, H. (1986). DNA methylation affects the formation of active chromatin. Cell 44: 535-543.

21. Kobayashi, H., Ngernprasirtsiri, J., and Akazawa, T. (1989). Transcriptional regulation and DNA methylation in plastids during transitional conversion of chloroplasts to chromoplasts. EMBO J. 9: 307-313.

22. Kobayashi, H., Bogorad, L., and Miles, C.D. (1987). Nuclear gene regulated expression of chloroplast genes for coupling factor one in maize. Plant Physiol. 85: 757-767.

23. Larkinua, I.M., Muskavitch, K.M.T., Gubbins, E.J., and Bogorad, L. (1983). A detailed restriction endonuclease site map of Zea mays plastid genome. Plant Mol. Biol. 2: 129-140.

24. Lescure, A. (1969). Mutagenèse et sélection de cellules d'Acer pseudoplatanus L. cultivées in vitro. Physiol. Vég. 7: 237-350.

25. LiNK, G. (1984). DNA sequence requirements for the accurate transcription of a protein-coding plastid gene in a plastid in vitro system from mustard (Sinapis alba L.). EMBO J. 3: 16971704.

26. Martin, C., Prescott, A., Lister, C., and Mackay, S. (1989). Activity of the transposon Tam 3 in Antirrhinum and tobacco: Possible role of DNA methylation. EMBO J. 8: $997-$ 1004.

27. Matzke, M.A., Primig, M., Trnovsky, J., and Matzke, A.J.M. (1989). Reversible methylation and inactivation of marker genes in sequentially transformed tobacco plants. EMBO J. 8: 643-649.

28. Mullet, J.E. (1988). Chloroplast development and gene expression. Annu. Rev. Plant Physiol. 39: 475-502.

29. Ngernprasirtsiri, J., Macherel, D., Kobayashi, H., and AKAZAWA, T. (1988). Expression of amyloplast and chloroplast DNA in suspension-cultured cells of sycamore (Acer pseudoplatanus L.). Plant Physiol. 86: 137-142.

30. Ngernprasirtsiri, J. and Kobayashi, H. (1990). Application of an efficient strategy with a phage $\lambda$ vector for constructing a physical map to the amyloplast genome of sycamore (Acer pseudoplatanus). Arch. Biochem. Biophys. 276: 172-179.

31. NGERNPrasirtsiri, J., KobaYashi, H., and AKaZAWA, T. (1988). DNA methylation as a mechanism of transcriptional regulation in nonphotosynthetic plastids in plant cells. Proc. Natl. Acad. Sci. USA 85: 4750-4754.

32. Ngernprasirtsiri, J., Kobayashi, H., and AKazawa, T. (1988). DNA methylation occurred around lowly expressed genes of plastid during tomato fruit development. Plant Physiol. 88: 16-20.

33. Ngernprastrtsiri, J., Kobayashi, H., and AKazawa, T. (1989). Transcriptional regulation and DNA methylation of nuclear genes for photosynthesis in nongreen plant cells. Proc. Natl. Acad. Sci. USA 86, 7919-7923.

34. Ngernprasirtsiri, J., Kobayashi, H., and AKazawa, T. (1990). Expression of photosynthetic genes is distinctly different between chloroplasts and amyloplasts in the liquid cultured 
cells of sycamore (Acer pseudoplatanus L.) Cell Struct. Funct. 15: $273-283$.

35. Ngernprasirtsiri, J., Chollet, R., Kobayashi, H., Sugiyama, T., and AKAZAWA, T. (1989). DNA methylation and the differential expression of $\mathrm{C}_{4}$ photosynthesis genes in mesophyll and bundle sheath cells of greening maize leaves. J. Biol. Chem. 264: 8241-8248.

36. Orozco, E.M. Jr., Mullet, J.E., and Chua, N.-H. (1985). An in vitro system for accurate transcription initiation of chloroplast protein genes. Nucleic Acids Res. 13: 1283-1302.

37. Peerbotte, R., Leenhouts, K., Hooykaas-van Slogteren, G.M.S., Wullems, G.J., and Shilperoort, R.A. (1986). Clones from a shooty tobacco crown gall tumor II: Irregular TDNA structures and organization, T-DNA methylation and conditional expression of opine genes. Plant Mol. Biol. 7: 285-299.

38. RazIN, A. and CEDAR, H. (1984). DNA methylation in eukaryotic cells. In International Reviews of Cytology volume 92 Nuclear Genetics, (J.F. Danielli ed.) Academic Press Inc. pp. $159-185$.

39. Shapiro, H.S. (1976). Distribution of purines and pyrimidines, and content of 6-methylaminopurine and 5-methylcytosine in DNA. In Handbook of Biochemistry and Molecular
Biology: Nucleic acids, 3rd Edition (G.D. Fasman ed.), pp. 241-283.

40. Spena, A., Viotti, A., and Pirrotta, V. (1983). Two adjacent genomic zein sequences: Structure, organization, and tissue specific restriction pattern. J. Mol. Biol. 169: 799-811.

41. Stirdivant, S.M., Crossland, L.D., and Bogorad, L. (1985). DNA supercoiling affects in vitro transcription of two maize chloroplast gene differently. Proc. Natl. Acad. Sci. USA 82: $4886-4890$.

42. Sugrta, M. and Sugiura, M. (1984). Nucleotide sequence and transcription of the gene for the 32,000 dalton thylakoid membrane protein from Nicotiana tabacum. Mol. Gen. Genet. 195: 308-313.

43. Umeno, M., Song, B.J., KozaK, C., Gelboin, H.V., and GonZales, F.J. (1988). The rat P450IIEl gene: Complete intron and exon sequences, chromosome mapping, and correlation of developmental expression with specific 5'-cytosine demethylation. J. Biol. Chem. 263: 4956-4962.

44. Watson, J.C., KaUfman, L.S., and Thompson, W.F. (1987). Development regulation of cytosine methylation in the nuclear ribosomal RNA genes of Pisum sativum. J. Mol. Biol. 193: 1526.

(Received for publication, June 26, 1990

and in revised form, July 20, 1990) 